\title{
Effects of the Physicochemical Properties of Lignocellulosic Artificial Soil Containing Bacillus subtilis on the Growth of Lespedeza cyrtobotrya ${ }^{1}$
}

\author{
$\mathrm{Ji}-\mathrm{Su} \mathrm{Kim}^{2} \cdot \mathrm{Ji}$ young $\mathrm{Jung}^{2} \cdot \mathrm{Si}$ Young $\mathrm{Ha}^{2} \cdot$ Jae-Kyung Yang $\mathbb{D}^{2, \dagger}$
}

\begin{abstract}
In this study, we prepared lignocellulosic artificial soil that contains Bacillus subtilis (peat moss/perlite/ steam-exploded oak wood $/$ microbial culture $=3: 1: 3: 3, \mathrm{w} / \mathrm{w} / \mathrm{w} / \mathrm{w}$ ) for use in the restoration of damaged soil areas. The prepared lignocellulosic artificial soil was mixed with soil at ratios of $0 \%$, $25 \%$, 50\%, $75 \%$, and $100 \%$. These mixed soils were then applied to fields, and the resultant physicochemical properties and their effects on the plant growth of Lespedeza cyrtobotrya were observed. The mixture of the prepared artificial soils (mixed at ratios of 25\%-100\%) with soil had a bulk densities of $<0.04 \mathrm{~g} / \mathrm{cm}^{3}$, porosities of $>85 \%$, $\mathrm{pH}$ values between 4.3 and 4.7 , electrical conductivities of $<0.5$ $\mathrm{dS} / \mathrm{m}, \mathrm{C} / \mathrm{N}$ ratios between 15.0 and 26.5 , organic matter content between $23.6 \%$ and $43.2 \%$, and bacterial densities between $157 \times 10^{6}$ and $624 \times 10^{6} \mathrm{CFU} / \mathrm{g}$. In addition, the prepared artificial soils mixed with soil at ratios of $25 \%-50 \%$ exhibited higher plant growth rates for L. cyrtobotrya compared with the control. Overall, we identified positive correlations between the plant growth of $L$. cyrtobotrya and soil bulk density, porosity, water-holding capacity, C/N ratio, organic matter, and bacterial densities.
\end{abstract}

Keywords: lignocellulosic, artificial soil, Bacillus subtilis, physicochemical properties, plant growth, Lespedeza cyrtobotrya

\section{INTRODUCTION}

Afforestation on damaged soil by natural restoration is a long process that can possibly produce conditions unfavorable for plant growth (Pritchett and Fischer, 1987). Artificial soil is commonly used to promote plant growth by improving the physicochemical properties of soil (Cao et al., 2014; Kerek, 2003). South Korean researchers have been evaluating methods of preparing artificial soil using organic wood materials such as Miscanthus sinensis var. purpurascens, waste wood chips, and pulp slurry (Kwon et al., 2014); waste wood chips and slurry (Kim and Kim, 2010); pre-treated wood chips and peat moss (Kim et al., 2016); incinerated paper mill sludge (Choi and Park, 2016); waste wood chips (Koh et al., 2010); raw straw mats, peat moss, and fermented wood chips (Jeong et al., 2010); high-temperature- or high-pressure-treated wood chips

\footnotetext{
1 Date Received May 2, 2019, Date Accepted July 2, 2019

2 Division of Environmental Forest Science, Major of Environmental Materials Science, Institute of Agriculture \& Life Science, Gyeongsang National University, Jinju 52828, Republic of Korea

† Corresponding author: Jae-Kyung Yang (e-mail: jkyang@gnu.ac.kr, ORCID: 0000-0003-0423-6398)
} 
(Moon et al., 2018; Kim et al., 2016); wood mill (Jo et al., 2017); and pine sawdust (Jung et al., 2017).

Artificial soil that contains wood material not only enhances soil structure, air permeability, and waterholding and cation exchange capacities (Cogger, 2005) but also promotes plant growth by supplying oxygen, moisture, and nutrients to the plant root systems (Bandaranayake et al., 2003). However, given that artificial soil is usually mixed with peat moss or perlite, the plant root system lacks the microorganisms necessary for effective promotion of plant growth. Ju et al. (2013) have reported that the microbes present in organic artificial soil protect plant roots and promote their growth. Other studies have claimed that these microbes are essential for nutrient absorption (Lange et al., 1993) and that they promote plant growth through direct and indirect interactions with plants (Juanda, 2005; Ahmad et al., 2008; Sayyed et al., 2009). Additionally, microbial activity can improve soil fertility by promoting soil aggregate formation (Oades, 1993; Tisdall, 1994; Six et al., 2007). These observations confirm that microbes significantly improve the physicochemical properties of artificial soil, thereby promoting plant growth. Despite the importance of developing new artificial soils that contain both microbes and wood materials, very few studies on the subject have been published in the literature (Jeon and Woo, 2005; Ma et al., 2011).

In this study, we prepared a wood-based artificial soil that was mixed with a control soil at varying ratios. We then planted seeds of Lespedeza cyrtobotrya in small outdoor pots. We evaluated the use of artificial soil in afforestation and identified the properties of the soil that affect the growth of $L$. cyrtobotrya by analyzing the physicochemical properties of the artificial soil and examining the stem and root growth of the plant.

\section{MATERIALS and METHODS}

\subsection{Testing materials}

Commercially available peat moss (pH 3.5-4.5, Sunshine, Canada), perlite (S company, Seoul, Korea), and carboxyl methyl cellulose (CMC, K company, Daejeon, Korea) were used in these experiments. Unseasoned Quercus mongolica chips were processed at a pressure of $25 \mathrm{kgf} / \mathrm{cm}^{2}$ in a high-temperature/ pressure processing machine ( $\mathrm{Y}$ company, Daegu, Korea) for $5 \mathrm{~min}$. Ethanol (10\%) was extracted from the wood chips at $60{ }^{\circ} \mathrm{C}$ for $3 \mathrm{~h}(1: 20 \mathrm{w} / \mathrm{v})$ and subjected to decompression filtration. The resulting solids were used in the next steps of the experiment.

\subsection{Preparation of microbial formulation and artificial soil}

Bacillus subtilis, the bacterial test strain used in this study, was acquired from $\mathrm{H}$ company (Jinju-si, Gyeongsangnam-do, Korea). The microbes were cultured in liquid broth at $30{ }^{\circ} \mathrm{C}$ and $100 \mathrm{rpm}$ for 4 days. Subsequently, $30 \mathrm{~mL}$ of the culture was added to $30 \mathrm{~mL}$ of $2 \% \mathrm{CMC}$ and incubated in $100 \mathrm{~g}$ of sterilized perlite at $30{ }^{\circ} \mathrm{C}$ for 8 days. The microbes were dried at $35{ }^{\circ} \mathrm{C}$ for $48 \mathrm{~h}$ and formulated with a freeze dryer to be used as a raw material for the artificial soil. Artificial soil was prepared by mixing peat moss, perlite, pre-processed Quercus mongolica chips, and the microbial formulation in a ratio of 3:1:3:3 (w/w/w/w).

\subsection{Plot design using small outdoor pots}

Before the experimental plots were established, the control soil (wetland soil from Cheongseongsan, Yangsan-si, Gyeongsangnam-do), 25\% mixed soil (75\% natural soil $+25 \%$ artificial soil, w/w), 50\% mixed soil (50\% natural soil $+50 \%$ artificial soil, w/w), 75\% mixed soil (25\% natural soil $+75 \%$ artificial soil, $w / w)$, 
Effects of the Physicochemical Properties of Lignocellulosic Artificial Soil Containing Bacillus subtilis on the Growth of Lespedeza cyrtobotrya

and $100 \%$ artificial soil were prepared (based on dry weights). The plots were set up by randomly placing the soils in cube-shaped pots $\left(7.5 \times 7.5 \times 7.5 \mathrm{~cm}^{3}\right)$ on a sloped surface at a latitude of $35.14 \mathrm{~N}$ and longitude of 128.09E. The pots were watered once every 3 days to prevent the soils from drying. Subsequently, 50 seeds of the woody plant L. cyrtobotrya were planted in the plots to analyze plant growth. The physicochemical properties and microbial densities of the control, mixed, and artificial soils were also assessed.

\subsection{Analysis of physicochemical properties}

The control, mixed, and artificial soils were dried at $60{ }^{\circ} \mathrm{C}$ for $24 \mathrm{~h}$ before analysis of the physicochemical properties. To measure bulk density, a $100-\mathrm{cm}^{3}$ core was filled with the sample, and pressure was applied for 3 min using a 500-g weight. Next, the top of the core was vertically cut from the container surface, and the sample was weighed to determine the bulk density (CEN, 1999a, 1999b; Byun et al., 2012). Porosity was calculated by applying the specific gravity (2.65) to the bulk density measurement (Inbar et al., 1993). To measure the water-holding capacity, a $100-\mathrm{cm}^{3}$ core was filled with the sample and pressured as described above. The sample was saturated with water, which was allowed to drain under gravity over $24 \mathrm{~h}$. The final weight of the dry sample was then measured to determine the water-holding capacity (Yi et al., 2012). The sample was mixed with distilled water (1:5, w/w) and then placed in a shaking incubator for $30 \mathrm{~min}$, after which the $\mathrm{pH}$ was measured using a $\mathrm{pH}$ meter (HI-8417, HANNA Instrument, USA). The electrical conductivity (EC) of the suspended filtrate was measured using an EC meter (Orion 3-Star, Plus, Thermo Fisher Scientific, USA). The content of organic matter was measured by completely carbonizing the sample in a muffle furnace (NIAST, 2000) at $550{ }^{\circ} \mathrm{C}$. The carbon-to-nitrogen $(\mathrm{C} / \mathrm{N})$ mass ratio was calculated using an elemental analyzer (Flash 2000 Series, Thermo Fisher Scientific Inc., USA).

\subsection{Analysis of plant growth characteristics}

The $50 \mathrm{~L}$. cyrtobotrya seedlings were allowed to germinate for 3 months; subsequently, 5 seedlings were randomly selected for plant growth analysis. The stem heights and root lengths of the seedlings were measured with a pair of calipers (Digital calipers, Blue bird, China) (Lee et al., 2013).

\subsection{Analysis of microbial density}

A total of 10-g (dry weight) samples of control, mixed, and artificial soil was collected before establishment of the plots, and equivalent $10 \mathrm{~g}$ of samples were collected taken after 3 months. The soils were mixed with $90 \mathrm{~mL}$ of sterilized $0.85 \% \mathrm{NaCl}$ solution and then placed in a shaking incubator (Vision Co., Bucheon, Korea) at $200 \mathrm{rpm}$ for $30 \mathrm{~min}$. The suspension was serially diluted, smeared, and cultured on R2A agar (NA, Difco, Detroit, MI) badge containing cycloheximide $(0.05 \mathrm{~g} / \mathrm{L})$. The plates were incubated at $28{ }^{\circ} \mathrm{C}$ for 2 days, and the number of colonies was counted. For each sample, the microbial number (CFU/ml) was calculated by averaging the counts from three Petri dishes (Oh et al., 2014).

\subsection{Statistical analysis}

All statistical analyses were performed using IBM SPSS statistics v25 (IBM Corp., Armonk, NY, USA). The Duncan's multiple range test $(p<0.05)$ was conducted to determine significance levels between the means of the experimental plots. Pearson's correlation coefficient analysis was used to investigate the correlation between the physicochemical properties of artificial soil and root/stem growth. 


\section{RESULTS and DISCUSSION}

\subsection{Physical properties}

Comparisons of the physical properties (e.g., bulk density, porosity, and water-holding capacity) of different soils are important because these parameters affect plant growth significantly (Boodley, 1998). Table 1 summarizes the bulk densities, porosities, and waterholding capacities of the control, mixed, and artificial soils.

The bulk densities of the $25 \%$ and $50 \%$ mixed soils were 0.24 and $0.16 \mathrm{~g} / \mathrm{cm}^{3}$, respectively. These measurements were significantly lower than that of the control soil $\left(0.51 \mathrm{~g} / \mathrm{cm}^{3}\right)$. The observed gradual decrease in bulk density was associated with an increase in the percentage of artificial soil. The level of organic matter in soil is thought to be negatively correlated to bulk density (Ju et al., 2015). The decrease in bulk density due to the presence of artificial soil has the advantage of improving water-holding capacity and air permeability (Nelson, 2003). Porosity has been shown to affect the drainage and water-holding capacity of soils and the growth of plant roots (Schoenholtz et al., 2000; Liebig and Doran, 1999). Plants are reported to grow well in soils with a porosity of $\geq 85 \%$ (De Boodt and Verdonck, 1972; Gruda and Schnitzler, 2004). Although the control soil had an inadequate porosity of $80.7 \%$, this porosity increased to $90.8 \%-95.5 \%$ by increasing the mixing ratio of the artificial soil. Although an increase in porosity can be beneficial for plant growth, it may also lead to an increase in permeability because moisture migrates through the pores, thereby subjecting plants to significant dehydration-induced damage (Shin, 2002). Therefore, natural and artificial soils must be mixed according to the soil conditions at the planting site, rather than solely using artificial soil with a high porosity. The water-holding capacity of a soil is the amount of water that it can store and is known to affect the distribution of water into the plant, a process that is essential for growth (Yang et al., 2013). The water-holding capacities of the control, 25\% mixed, $50 \%$ mixed, $75 \%$ mixed, and artificial soils were found to be $59.9 \%, 66.1 \%, 76.5 \%, 79.8 \%$, and $83.3 \%$, respectively. These findings demonstrate the positive correlation between water-holding capacity and the mixing ratio of the artificial soil. The water-holding capacity of the soils in all the experimental plots (except the control) was $>60 \%$, which is considered adequate (Yeager et al., 1997). Basso et al. (2013) and Lawes et al. (2009) have reported that high water-holding capacity is beneficial for long-term plant growth and soil loss prevention. These benefits can be achieved by the on-site application of artificial soil as prepared in this study. In addition, increases in the bulk density, porosity and water-holding capacity of the soils were achieved by increasing the ratio of the artificial soil, relative to the control soil.

Table 1. Physical properties on mixing ratio of artificial soil with soil.

\begin{tabular}{cccc}
\hline Media $^{1)}$ & Bulk density $\left(\mathrm{g} / \mathrm{cm}^{3}\right)$ & Porosity (\%) & Water holding capacity (\%) \\
\hline \hline Soil & $0.51 \pm 0.01 \mathrm{a}^{2}$ & $80.70 \pm 0.20 \mathrm{e}$ & $59.90 \pm 1.30 \mathrm{e}$ \\
$25 \%$ mixed soil & $0.24 \pm 0.02 \mathrm{~b}$ & $90.80 \pm 0.10 \mathrm{~d}$ & $66.10 \pm 0.40 \mathrm{~d}$ \\
$50 \%$ mixed soil & $0.16 \pm 0.02 \mathrm{c}$ & $94.10 \pm 0.30 \mathrm{c}$ & $76.50 \pm 0.50 \mathrm{c}$ \\
$75 \%$ mixed soil & $0.13 \pm 0.03 \mathrm{c}$ & $95.00 \pm 0.50 \mathrm{~b}$ & $79.80 \pm 1.50 \mathrm{~b}$ \\
Artificial soil & $0.08 \pm 0,00 \mathrm{~d}$ & $97.00 \pm 0.70 \mathrm{a}$ & $83.30 \pm 0.10 \mathrm{a}$ \\
\hline
\end{tabular}

\footnotetext{
1) Soil: $100 \%$ soil, control; $25 \%$ mixed soil: $75 \%$ soil and $25 \%$ artificial soil, (w/w); $50 \%$ mixed soil: $50 \%$ soil and $50 \%$ artificial soil, (w/w); 75\% mixed soil: $25 \%$ soil and 75\% artificial soil, (w/w); Artificial soil: $100 \%$ artificial soil.

${ }^{2)}$ Different letters within same column indicate the significant difference at $p<0.05$ by Duncan's multiple range test
} 
Effects of the Physicochemical Properties of Lignocellulosic Artificial Soil Containing Bacillus subtilis on the Growth of Lespedeza cyrtobotrya

\subsection{Chemical properties}

The chemical properties of soils are important determinants of plant growth and appropriate environment (Gabriels et al., 1986). Accordingly, a comparative analysis of the soil components should be conducted with reference to ratios of control to artificial soil. Table 2 summarized the $\mathrm{pH}, \mathrm{EC}, \mathrm{C} / \mathrm{N}$ ratio, and organic matter content of the control, mixed, and artificial soils.

The $\mathrm{pH}$ of the control, 25\% mixed, 50\% mixed, and $75 \%$ mixed soils were 4.8, 4.7, and 4.6, respectively. These values are lower than the optimal $\mathrm{pH}$ range for plant growth, i.e., 5.3-6.5 (Abad et al., 1992). Significant differences in $\mathrm{pH}$ were not observed between the soils containing different percentages of artificial soil. The artificial soil was found to have the lowest $\mathrm{pH}$ at 4.3. Yamazaki (1982) have reported that plant roots are easily damaged at a $\mathrm{pH}$ of $<$ four. These observations highlight the need to adjust the $\mathrm{pH}$ of soils according to local conditions to optimize plant growth. The EC of the control, mixed, and artificial soils were measured between 0.061 and $0.101 \mathrm{ds} / \mathrm{m}$. ECs of $\leq 0.5 \mathrm{ds} / \mathrm{m}$ are generally considered adequate for plant growth (Abad et al., 2002). High ECs can result in salt accumulation and poor conditions for root growth (Aliasgharzadeh et al., 2001). As such, we suggest that the low EC of the artificial soil prevents salt-induced growth inhibition. A high $\mathrm{C} / \mathrm{N}$ ratio promotes microbial absorption of nitrogen in the root-zone around the plant, thereby hindering early growth (Choi et al., 2011). For this reason, nitrogen fertilizers should be added if the $\mathrm{C} / \mathrm{N}$ ratio of the artificial soil is $\geq 50$ (Lee and Sang, 1991). Sou et al. (2011) have reported a $\mathrm{C} / \mathrm{N}$ ratio of 17.4 in a habitat containing L. cyrtobotrya. In the present study, the $25 \%$ mixed, $50 \%$ mixed, and $75 \%$ mixed soils showed $\mathrm{C} / \mathrm{N}$ ratios ranging from 15.0 to 19.8 , thus suggesting that varying amounts of artificial soil are unlikely to inhibit early growth. The control soil showed the lowest organic matter content (23.6\%); however, as the mixing ratio of the artificial soil increased, the organic matter significantly increased from $27.6 \%$ to $43.2 \%$ possibly because of the addition of pre-processed oak and peat moss, which are rich in organic materials, to the artificial soil. High levels of organic matter provide large amounts of nutrients to the plant and improve the cation exchange capacity necessary for small nutrient exchanges (Wood et al., 2018).

\subsection{Microbial density}

Table 3 presents the microbial densities before and after the on-site application of the control, mixed, and artificial soils in small outdoor pots.

Prior to the on-site application, the control soil had the lowest microbial density of $3.5 \times 10^{7} \mathrm{CFU} / \mathrm{g}$. This microbial density increased from $1.57 \times 10^{8}$ to 6.24 $\times 10^{8} \mathrm{CFU} / \mathrm{g}$ as the ratio of the artificial soil increased.

Table 2. Chemical properties on mixing ratio of artificial soil with soil

\begin{tabular}{cccc}
\hline Media $^{1)}$ & $\mathrm{pH}$ & EC $(\mathrm{ds} / \mathrm{m})$ & C/N ratio \\
\hline \hline Soil & $4.8 \pm 0.15 \mathrm{a}^{2)}$ & $0.061 \pm 0.001 \mathrm{c}$ & $11.0 \pm 0.1 \mathrm{e}$ \\
$25 \%$ mixed soil & $4.7 \pm 0.20 \mathrm{a}$ & $0.065 \pm 0.002 \mathrm{c}$ & $15.0 \pm 0.2 \mathrm{~d}$ \\
$50 \%$ mixed soil & $4.7 \pm 0.12 \mathrm{a}$ & $0.066 \pm 0.004 \mathrm{c}$ & $17.7 \pm 0.2 \mathrm{c}$ \\
$75 \%$ mixed soil & $4.6 \pm 0.13 \mathrm{a}$ & $0.076 \pm 0.003 \mathrm{~b}$ & $19.8 \pm 0.1 \mathrm{~b}$ \\
Artificial soil & $4.3 \pm 0.10 \mathrm{~b}$ & $0.101 \pm 0.003 \mathrm{a}$ & $26.5 \pm 0.3 \mathrm{a}$ \\
\hline
\end{tabular}

\footnotetext{
1) Soil: $100 \%$ soil, control; $25 \%$ mixed soil: $75 \%$ soil and $25 \%$ artificial soil, (w/w); $50 \%$ mixed soil: $50 \%$ soil and $50 \%$ artificial soil, (w/w); $75 \%$ mixed soil: $25 \%$ soil and $75 \%$ artificial soil, (w/w); Artificial soil: $100 \%$ artificial soil

${ }^{2)}$ Different letters within same column indicate the significant difference at $p<0.05$ by Duncan's multiple range test
} 
Table 3. Change of bacteria density in mixing ratio of artificial soil with soil on field application

\begin{tabular}{ccc}
\hline & \multicolumn{2}{c}{ Bacteria $\left(\times 10^{6}\right.$, CFU/g) } \\
\cline { 2 - 3 } Media $^{1)}$ & \multicolumn{2}{c}{ Field application } \\
\cline { 2 - 3 } & Before & After \\
\hline \hline Soil & $35 \pm 5.3 \mathrm{e}^{2)}$ & $30 \pm 7.1 \mathrm{e}$ \\
$25 \%$ mixed soil & $157 \pm 10.4 \mathrm{~d}$ & $253 \pm 29.1 \mathrm{~d}$ \\
$50 \%$ mixed soil & $334 \pm 15.1 \mathrm{c}$ & $437 \pm 10.2 \mathrm{c}$ \\
$75 \%$ mixed soil & $440 \pm 20.3 \mathrm{~b}$ & $532 \pm 32.1 \mathrm{~b}$ \\
Artificial soil & $624 \pm 41.2 \mathrm{a}$ & $854 \pm 21.2 \mathrm{a}$ \\
\hline
\end{tabular}

1) Soil: $100 \%$ soil, control; $25 \%$ mixed soil: $75 \%$ soil and $25 \%$ artificial soil, (w/w); $50 \%$ mixed soil: $50 \%$ soil and $50 \%$ artificial soil, (w/w); $75 \%$ mixed soil: $25 \%$ soil and $75 \%$ artificial soil, (w/w); Artificial soil: $100 \%$ artificial soil

${ }^{2)}$ Different letters within same column indicate the significant difference at $p<0.05$ by Duncan's multiple range test

After 3 months, the microbial density of the control soil had decreased by $13.4 \%$. Conversely, the microbial numbers of the $25 \%, 50 \%$, and $75 \%$ mixed soils and the artificial soil had increased by $61.1 \%, 30.8,21$, and $36.9 \%$, respectively. These increases can be explained by the ability of microbes to use organic carbon and nitrogen sources as macronutrients for plant growth. Moreover, the artificial soil prepared in this study contained peat moss and wood materials comprising organic matter that is beneficial for microbial growth (Barber and Lynch, 1997; Lynch, 1982; Krieg and Holt, 1984). An increase in microbial density is known to positively affect plant growth (Nautiyal et al., 2013).
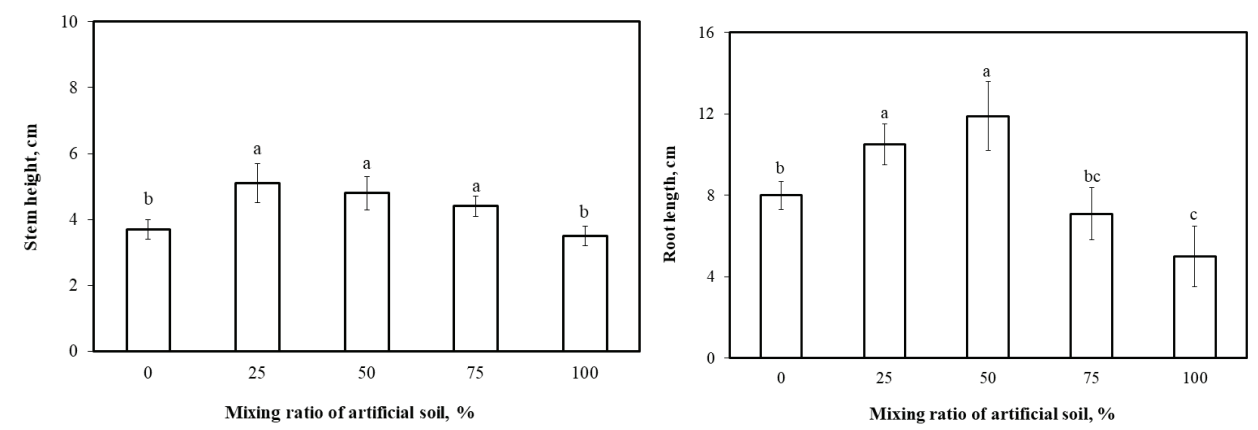

Fig. 1. Effect of mixing ratio of artificial soil with soil on growth of Lespedeza cyrtobotrya.
Fig. 1 illustrates stem heights and root lengths of L. cyrtobotrya planted in small outdoor pots containing the control, mixed, and artificial soils.

The longest stem was $5.1 \mathrm{~cm}$ in the $25 \%$ mixed soil. Stem lengths in the $50 \%$ and $75 \%$ mixed soils and the artificial soil were $4.8,4.4$, and $3.5 \mathrm{~cm}$, respectively. Stem growth decreased in the $50 \%$ (or above) mixed soil. The longest root length was $11.9 \mathrm{~cm}$ in the $50 \%$ mixed soil, followed by $10.5,8,7$, and $5 \mathrm{~cm}$ in the $25 \%$ mixed, control, $75 \%$ mixed, and artificial soils, respectively, although artificial soil is thought to improve plant growth by improving water and air permeability (Warkentin, 1984; Kang et al., 2004); 
Effects of the Physicochemical Properties of Lignocellulosic Artificial Soil Containing Bacillus subtilis on the Growth of Lespedeza cyrtobotrya

Table 4. The values of correlation coefficient $(r)^{1)}$ between physicochemical properties of artificial soil and growth characteristics of Lespedeza cyrtobotrya

\begin{tabular}{|c|c|c|c|c|c|c|c|c|c|c|}
\hline & $\begin{array}{l}\text { Bulk } \\
\text { density }\end{array}$ & Porosity & $\begin{array}{l}\text { Water } \\
\text { holding } \\
\text { capacity }\end{array}$ & $\mathrm{pH}$ & $\begin{array}{l}\text { Electrical } \\
\text { conductivity }\end{array}$ & $\mathrm{C} / \mathrm{N}$ ratio & $\begin{array}{l}\text { Organic } \\
\text { matter }\end{array}$ & $\begin{array}{l}\text { Bacterial } \\
\text { density }\end{array}$ & $\begin{array}{l}\text { Stem } \\
\text { height }\end{array}$ & $\begin{array}{l}\text { Root } \\
\text { length }\end{array}$ \\
\hline Bulk density & 1 & $-0.965^{* *}$ & $-0.933^{* *}$ & 0.174 & -0.149 & - $-0.824^{* *}$ & $-0.764^{* *}$ & $-0.770^{* * *}$ & -0.239 & $0.336^{* *}$ \\
\hline Porosity & & 1 & $0.887^{* *}$ & -0.133 & 0.192 & $0.780^{* *}$ & $0.700^{* *}$ & $0.724^{* *}$ & 0.242 & $-0.318^{*}$ \\
\hline $\begin{array}{l}\text { Water holding } \\
\text { capacity }\end{array}$ & & & 1 & -0.204 & 0.103 & $0.830^{* *}$ & $0.762^{* *}$ & $0.807^{* *}$ & $0.338^{* *}$ & $-0.281^{*}$ \\
\hline $\mathrm{pH}$ & & & & 1 & $-0.575^{* *}$ & $-0.328^{*}$ & $-0.380^{* *}$ & $-0.289^{*}$ & -0.122 & -0.065 \\
\hline $\begin{array}{l}\text { Electrical } \\
\text { conductivity }\end{array}$ & & & & & 1 & $0.294^{*}$ & $0.342^{* *}$ & 0.174 & -0.135 & -0.233 \\
\hline $\mathrm{C} / \mathrm{N}$ ratio & & & & & & 1 & $0.948^{* *}$ & $0.952^{* *}$ & $0.389^{* *}$ & $-0.357^{* *}$ \\
\hline Organic matter & & & & & & & 1 & $0.922^{* *}$ & $0.361^{* *}$ & $-0.383^{* *}$ \\
\hline Bacterial density & & & & & & & & 1 & $0.599^{* *}$ & -0.138 \\
\hline Stem height & & & & & & & & & 1 & $0.547^{* *}$ \\
\hline Root length & & & & & & & & & & 1 \\
\hline
\end{tabular}

1) Correlation coefficient $(r)$ was determined by Pearson correlation analysis to evaluate the relationship between parameters. Results were evaluated with 95\% and 99\% confidence intervals: *, significant at $p<0.05$ and $* *$, significant at $p<0.01$ level

however, this association was not observed between stem and root lengths and the ratio of artificial soil in the potting mix. This suggests that the appropriate mixing ratio of artificial soil must be determined for the target plant.

\subsection{Correlation between the physicochemical properties of artificial soil and the growth of $\mathrm{L}$. cyrtobotrya}

Table 4 shows a correlation analysis of the effects of the physicochemical properties of soils on the stem and root growth of L. cyrtobotrya.

A positive correlation between the physicochemical properties of the soils and stem/root growth was observed in terms of microbial density, $\mathrm{C} / \mathrm{N}$ ratio, organic matter content, and water-holding capacity ( $p$ $<0.01)$. Microbial density and stem growth showed the most significant positive correlation with a correlation coefficient of 0.599 . Our finding that porosity correlates with stem growth is in agreement with the report of Jo et al. (2017). The root growth of $L$. cyrtobotrya was found to positively correlate with bulk density $(p<0.01)$ but negatively correlate with porosity, water-holding capacity, $\mathrm{C} / \mathrm{N}$ ratio, and organic matter content.

\section{CONCLUSION}

The bulk density of the mixture of artificial and control soils was $<0.4 \mathrm{~g} / \mathrm{cm}^{3}$, porosity was $>85 \%$, and water-holding capacity was $>60 \%$. Regarding its chemical properties, the soil showed an EC of $<0.5$ $\mathrm{ds} / \mathrm{m}$, a $\mathrm{C} / \mathrm{N}$ ratio of $<50$, and a high concentration of organic matter. Based on the data for bulk density, porosity, and water-holding capacity, the soil showed appropriate physicochemical properties required for optimal plant growth. However, the $\mathrm{pH}$ of the artificial soil prepared in this study was slightly acidic, thus making it necessary to adjust its $\mathrm{pH}$ according to the site conditions. The root and stem growth rates of $L$. cyrtobotrya were higher in the $25 \%$ and $50 \%$ mixed soils than in the control soil. Microbial density had the greatest impact on stem growth, whereas the organic 
matter content was the main effector of root growth. Based on these results, we demonstrate that the artificial soil prepared in this study effectively promotes the stem and root growth of L. cyrtobotrya and can, therefore, be used in the revegetation of habitats.

\section{ACKNOWLEDGMENT}

This study was carried out with the support of 'R\&D Program for Forest Science Technology (Project No. 2017091C101919AB01)’ provided by Korea Forest Service(Korea Forestry Promotion Institute).

\section{REFERENCES}

Abad, M., Martínez, P.F., Martínez, M.D., Martínez, J. 1992. Evaluación agronómica de los sustratos de cultivo. Actas de Horticultura 11: 141-154.

Abad, M., Noguera, P., Bures, S. 2001. National inventory of organic wastes for use as growing media for ornamental potted plant production: case study in Spain. Bioresource Technology 77: 197-200.

Ahmad, F., Ahmad, I., Khan, M. 2008. Screening of free-living rhizospheric bacteria for their multiple plant growth promoting activities. Microbiological Research 163(2): 173-181.

Aliasgharzadeh, N., Saleh Rastin, N., Towfighi, H., Alizadeh, A. 2001. Occurrence of arbuscular mycorrhizal fungi in saline soils of the Tabriz Plain of Iran in relation to some physical and chemical properties of soil. Mycorrhiza 11: 119-122.

Bandaranayake, W., Qian, Y.L., Parton, W.J., Ojima, D.S., Follett, R.F., 2003, Estimation of soil organic carbon changes in turfgrass systems using the century model. Agronomy Journal 95(3): 558-563.

Barber, D.A., Lynch, J.M. 1997. Microbial growth in the rhizosphere. Soil Biology and Biochemistry 9(5): 305-308.

Basso, A.S., Miguez, F.E., Laird, D.A. Horton, R.,
Westgate, M. 2013. Assessing potential of biochar for increasing water holding capacity of sandy soils. GCB Bioenergy 5(2): 132-143.

Boodley, J.W. 1998. The commercial greenhouse (2nd edition). Delmar Publishers, New York. pp. 140142.

Byun, H.J., Kim, Y.S., Kang, H.M., Kim, I.S. 2012. Physico-chemical Characteristics of used Plug Media and its Effect on Growth Response of Tomato and Cucumber Seedlings. Journal of Bio-environment Control. 21(3): 207-212.

Cao, C.T.N., Farrell, C., Kristiansen, P.E., Rayner, J.P. 2014. Biochar makes green roof substrates lighter and improves water supply to plants. Ecological Engineering 7: 2018-2027.

CEN (European committee for standardization). 1999a. Soil improvers and growing media-Sample preparation for chemical and physical tests, determination of dry matter content, moisture content and laboratory compacted bulk density. CEN. prEN 13040.

CEN (European committee for standardization). 1999b. Soil improvers and Growing media-Determination of physical properties-Dry bulk density, air volume, water volume, shrinkage value and total pore space. CEN. prEN 13041.

Cho, J.L., Lee, Y., Choi, H.S., Kim, W.S. 2011. The Effects of Organic Materials on Yield and N Use Efficiency of Organic Rice Grown under Frequent Heavy Rains. Korean Journal of Environmental Agriculture 30(2): 138-143.

Choi, J.H., Park, B.J. 2016. Growth response of lettuce according to mixing ratios of paper mill sludge and horticultural substrate, Journal of Korea TAPPI 48(4): 92-98.

Cogger, C.G., 2005, Potential compost benefits for restoration of soils disturbed by urban development. Compost Science Utilization 13: 243-251.

De Boodt, M., Verdonck, O. 1972. The physical pro- 
Effects of the Physicochemical Properties of Lignocellulosic Artificial Soil Containing Bacillus subtilis on the Growth of Lespedeza cyrtobotrya

perties of the substrates in horticultuer. Acta Horticulturae 26: 37-44.

Gabriels, R., Verdonck, O., Mekers, O. 1986. Substrate requirement for pot plants in recirculating water culture. Acta Horticulturae 178: 93-99.

Gruda, N., Schnitzler, W.H. 2004. Suitability of wood fiber substrate for production of vegetable transplants, I . Physical properties of wood fiber substrates. Scientia Horticulturae 100(1-4): 309-322.

Inbar, Y., Hadar, Y., Chen, Y. 1993. Recycling of cattle manure: the composting process and characterization of maturity. Journal of Environmental Quality 22(4): 857-863.

Jeon, G.S., Woo, K.J. 2005. A Study on application test of cut-slope revegetation measures with organic soil amendment materials. Journal of the Korea Society of Environmental Restoration Technology 8(3): 13-20.

Jeong, Y.H., Im, J.H., Lee, L.K., Seo, K.W., Lee, C.H. 2010. Comparison of Seedling Growth by Treatments of Vegetation Basis in an Abandoned Coal Mine Area. Journal of the Korea Society of Environmental Restoration Technology 13(6) : 87-96.

Jo, J.S., Ha, S.Y., Jung, J.Y., Kim, J.S., Nam, J.B., Yang, J.K. 2017. Effects of Lignocellulosic Growing Media to The Prevention of Forest Soil Erosion. Journal of the Korean Wood Science and Technology 45(4): 419-431.

Ju, J.H., In, D.Y., Kim, W.T., Yoon, Y.H., Choi, E.Y. 2015. Effects of Soil Organic Amendment as Plant Growing Media Component for Restoration of Planting Ground. Journal of Environmental Science International 24(11): 1363-1370.

Ju, J.H., Lee, S.Y., Yoon, Y.H. 2013. Effect of Organic Soil Conditioner Ratio on the Soil Moisture Content and Growth of Cotoneater horizontalis in the Container Type for Wall-Planting under Nonirrigation. Journal of the Environmental Sciences.
22(1): 17-23.

Jung, J.Y., Ha, S.Y., Yang, J.K. 2017. Steam Treated Sawdust as Soilless Growing Media for Germination and Growth of Horticulture Plant. Journal of the Korean Wood Science and Technology 45(6): 857-871.

Juanda, J. 2005. Screening of soil bacteria for plant growth promoting activities in vitro. Indonesian Journal of Agricultural Science 4(1): 27-31.

Kang J.Y., Lee, H.H., Kim, K.H. 2004. Physical and chemical properties of inorganic horticultural substrates used in Korea. Acta Horticulturae. 644: 237-241.

Kerek, M. 2003. Labile soil organic matter as a potential nitrogen source in golf greens. Soil Biology and Biochemistry 35(12) : 1643-1649.

Kim, D.Y., Kim, M.M. 2010. A Study on Manufactural Condition of Vegetation Mat for Greening Impermeable Surfaces Using Wood Waste. Journal of the Korean Wood Science and Technology 38(3): 165-169.

Kim, J.S., Jung, J.Y., Ha, S.Y., Yang, J.K. 2016. Physicochemical Properties and Growth Characteristics of Wood Chip and Peat Moss Based Vegetation Media. Journal of the Korean Wood Science and Technology 44(3): 323-336.

Koh J.H., Hur, Y.J., Lee, Y.K., Kim, N.C. 2010. A Study on the Use of Wood Waste for Slope Revegetation Techniques. Journal of the Korean Society of Environmental Restoration Technology 13(1): 47-56.

Krieg, N.R., Holt, J.G. 1984. Bergey’s manual of systematic bacteriology. Williams and Wilkins, Baltimor, pp. 215-232.

Kwon, G.J., Kim, E.J., Park, H.J., Kim, D.Y. 2014 Characteristics of the Vegetation Mat Prepared from Miscanthus Sinensis var. Purpurascens. Journal of the Korean Wood Science and Technology 42(1): 27-33. 
Lange, L., Breinholt, J., Rasmussen, F.W., Nielsen, R.I. 1993. Microbial fungicides - the natural choice. Pesticide Science 39(2): 155-160.

Lawes, R.A., Oliver, Y.M., Robertson, M.J. 2009. Integrating the effects of climate and plant available soil water holding capacity on wheat yield. Field Crops Research 113(3): 297-305.

Lee, J.S., Sang, C.G. 1991. Studies on the present status of cultivation and utilization of foliage plants. Journal of the Korean Society for Horticultural Science 32(2): 368-381.

Lee, S.Y., Kim, W.T., Ju, J.H., Yoon, Y.H. 2013. Effect of Calcium Chloride Concentration on Roadside Ground Cover Plant Growth. Journal of Korean Institute of Landscape Architecture 41(4): 17-23.

Liebig, M.A., Doran, J.W. 1999. Impact of organic production practices on soil quality indicators. Journal of Environmental Quality 28(5): 16011609.

Lynch, J.M. 1982. Interaction between bacteria and plants in the root environment In: Dommergues, R. and Krupa, S.V. (eds.). Society for Applied Bacteriology Symposium Series. 10. Academic Press, London/New York. pp. 1-23.

Ma, H.S., Kang, W.S., Park, J.W. 2011. Development of revegetation measures using boring technique in rock slopes. Journal of Korean Society of Forest Science 100(4): 558-564.

Moon, H.D., Ha, S.Y., Jung, J.Y., Yang, J.K. 2018. Physicochemical Properties and Plant Coverage of Wood-based Growing Media on Slopes. Journal of the Korean Wood Science and Technology 46(6): 645-655.

Nautiyal, C.S., Srivastava, S., Chauhan, P.S., Seem, K. Mishra, A., Sopory, S.K. 2013. Plant growthpromoting bacteria Bacillus amyloliquefaciens NBRISN13 modulates gene expression profile of leaf and rhizosphere community in rice during salt stress. Plant Physiology and Biochemistry 66: 1-9.
Nelson, P.V. 2003. Greenhouse operation and management, 6th ed. Prentice Hall. Englewood Cliffs, NJ.

NIAST. 2000. Method of soil and plant analysis, National Institute of Agriculture Science and Technology, Suwon.

Oades, J.M. 1993. The role of biology in the formation, stabilization and degradation of soil structure. Soil Structure/Soil Biota Interrelationships 56(1-4): 377-400.

Oh, Y.J., Sohn, S.I., Song, Y.I., Kang, S.B., Choi, J.H. 2014. Effects of Cover Plants on Soil Microbial Community in a Organic Pear Orchard. Korean Journal of Soil Science and Fertilizer 47(1): 28-35.

Pritchett, W.L., Fischer, R.F. 1987. Properties and management of forest soils. New York: Wiley.

Sayyed, R., Chincholkar, S. 2009. Siderophoreproducing Alcaligenes feacalis exhibited more biocontrol potential Vis-à-Vis chemical fungicide. Current Microbiology 58(1): 47-51.

Schoenholtz, S.H., Miegroet, H.V., Burger, J.A. 2000. A review of chemical and physical properties as indicators of forest soil quality: challenges and opportunities. Forest Ecology and Management 138(1-3): 335-356.

Shin, M.S. 2002. Roof and Wall-greening Technology Guide: Urban-greening Technology in the Age of Environmental Symbiosis. Building age. Architecture age publishing company.

Six, J., Bossuyt, H., Degryze, S., Denef, K. 2007. A history of research on the link between (micro) aggregates, soil biota, and soil organic matter dynamics. Soil and Tillage Research 79: 7-31.

Sou, H.D.,, Hur, T.C.,, Jung, S.C.,, Joo, S.H., Park, H. 2011. Analysis of Environmental Characteristics in Habitat of Amanita hemibapha. The Korean Journal of Mycology 39(3): 164-170.

Tisdall, J.M. 1994. Possible role of soil microorganisms in aggregation in soils. Plant and Soil 159(1): 
Effects of the Physicochemical Properties of Lignocellulosic Artificial Soil Containing Bacillus subtilis on the Growth of Lespedeza cyrtobotrya

115-121.

Warkentin, B. 1984. Physical properties of forest-nursery soils: Relation to seedling growth.(In Duryea, M.L. and Landis, T.D. Eds., "Forest Nursery Manual: Production of Bareroot Seedlings”). Hague: Springer Netherlands. pp. 53-61.

Wood, S.A., Tirfessa, D., Baudron, F. 2018. Soil organic matter underlies crop nutritional quality and productivity in smallholder agriculture. Agriculture, Ecosystems \& Environment 266: 100-108.

Yang L., Maosheng G., Wei W., Sikander K.T., Xiaoxia W., Yuncheng L. 2013. The effects of conservation tillage practices on the soil water-holding capacity of a non-irrigated apple orchard in the Loess
Plateau, China. Soil and Tillage Research 130: 7-12. Yamazaki, K., 1982, Management of $\mathrm{pH}$ in nutrient solution in hydroponics. Agriculture and Horticulture 57(2): 327-331.

Yeager, T., Gilliam, C., Bilderback, T.E., Fare, D., Niemiera, A., Tilt, K., 1997. Best Management Practices, Guide for producing container-grown plants. Southern Nursery Association, Atlanta.

Yi, Y.M., Oh, C.T., Kim, G.J., Lee, C.H., Sung, K.J. 2012. Changes in the Physicochemical Properties of Soil According to Soil Remediation Methods. Journal of Soil and Ground water Environment 17(4): 36-43. 


\title{
APPENDIX
}

\author{
(Korean Version)
}

\section{Bacillus subtilis가 함유된 목질계 인공토양의 물리·화학적 특성이 참싸리 생육에 미치는 영향}

초록 : 본 연구에서는 Bacilluls subtilis가 함유된 목질계 인공토양(피트모스:펄라이트:폭쇄처리된 참나무:미생물제형 $=3: 1: 3: 3, \mathrm{w} / \mathrm{w} / \mathrm{w} / \mathrm{w})$ 을 제조 하였으며, 이를 대조구토양과 $0 \%, 25 \%, 50 \%, 75 \%$ 및 $100 \%$ 비율로 혼합하여 참싸리 종자 파종 후 소규모 야외포트 현장적용 하였다. 현장적용에 따른 대조구토양, 혼합토양(대조구토양+인공토양) 및 인공토양의 물리·화학적 특성을 분석하였고 참싸리 줄기 및 뿌리생장을 비교하였다. 혼합토양에서는 $0.04 \mathrm{~g} / \mathrm{cm}^{3}$ 이하의 용적밀도, $85 \%$ 이상의 공극률, $\mathrm{pH} 4.3$ - 4.7, $0.5 \mathrm{dS} / \mathrm{m}$ 이하의 전기전도도, 15.0 - 26.5의 탄질비, $23.6 \%$ - 43.2\%의 유기물 함량 및 $157 \times 10^{6} \mathrm{CFU} / \mathrm{g}-$ $624 \times 10^{6} \mathrm{CFU} / \mathrm{g}$ 의 미생물밀도를 나타냈다. 인공토양이 $25 \%$ 및 $50 \%$ 함유된 혼합토양에서는 참싸리 줄기 및 뿌리생장이 대조구토양보다 높게 나타났고 참싸리의 생장에 영향을 미치는 토양 인자는 용적밀도, 공극률, 수분보유력, 탄질비, 유기물함량 및 미생물함량으로 나타났다.

\section{1. 서 론}

훼손된 토양은 자연 복원력만으로 녹화되기까지 오랜 시간이 소요되고 식물생육에 불리한 조건을 나타내게 된다(Pritchett and Fischer, 1987). 원활한 식물생장을 위하여 토양의 물리·화학적 특성을 향상시키는 것이 중요하며, 이를 위하여 주로 인공토 양을 이용한다(Cao et al., 2014; Kerek, 2003). 국내에서는 인공토양개발을 위해 거대억새, 폐목재칩과 펄프슬러리(Kwon et al., 2014), 폐목재칩과 슬러리(Kim and Kim, 2010), 전처리된 목재칩과 피트모스(Kim et al., 2016), 제지슬러지(Choi and Park, 2016), 임목폐기물 파쇄칩(Koh et al., 2010), 볏짚 거적, 피트모스와 목질칩(Jeong et al., 2010), 고온·고압 수증기처리 된 목재칩(Moon et al., 2018; Kim et al., 2016), 우드밀(Jo et al., 2017), 소나무 톱밥(Jung et al., 2017)등 유기질인 목질원료를 적용한 인공토양제조 연구가 진행되고 있다.

목질원료가 포함된 인공토양은 토양구조, 통기성, 보수성, 양이온치환용량 등을 높여줄 뿐 아니라(Cogger, 2005), 식물의 근계에 산소, 유효 토양수분, 영양분 등을 공급하여 식물생장에 도움을 준다(Bandaranayake et al., 2003). 하지만 목질원료가 포함된 인공토양은 주로 피트모스 또는 펄라이트와 혼합하여 이용하므로 식물의 생장을 촉진시키기 위한 유효미생물이 부족하 다. Ju et al. (2013)은 유기질 인공토양에 포함되어 있는 미생물이 식물의 근부를 보호하고 뿌리 생장에 도움을 준다고 보고했다. 뿐만 아니라 식물이 영양분을 흡수하고 생장하기위해 필요하고(Lange et al., 1993) 식물과의 다양한 상호작용을 통해 식물생장 을 직·간접적인 방식으로 향상시킨다고 보고되었다(Juanda, 2005; Ahmad et al., 2008; Sayyed et al., 2009). 또한, 미생물 활성의 효과로 토양의 입단형성을 촉진시켜 비옥도를 향상시킬 수 있다고 알려져 있으므로(Oades. 1993; Tisdall, 1994; Six et al., 2007) 인공토양에 적용시 물리·화학적 특성과 식물생장에 효과적일 것으로 판단된다. 따라서 미생물과 목질원료가 동시에 포함된 인공토양의 개발이 필요함에도 불구하고 현재까지 이에 대한 연구는 미비하다(Jeon and Woo, 2005; Ma et al., 2011).

본 연구에서는 미생물이 함유된 목질계 인공토양을 제조하였고 토양과 비율을 다르게 혼합한 다음 참싸리 종자를 파종하여 소규모 야외포트 현장적용 하였다. 현장적용에 따른 인공토양의 물리·화학적 특성과 참싸리의 줄기 및 뿌리생장을 분석함으로써 녹화용 소재로서의 활용가능성과 참싸리 생장에 영향을 미치는 인공토양의 물리화학적 특성 인자를 검토하였다.

\section{2. 재료 및 방법}

\section{1. 공시재료}

본 연구에 사용된 피트모스(pH 3.5 - 4.5, Sunshine, Canada) 및 펄라이트(S사, Seoul, Korea), CMC (carboxyl methyl cellulose, K사, Daejeon, Korea)는 시중에 판매하는 제품을 구입하여 사용하였다. 참나무(Quercus mongolica)칩은 생재 상태로 고온·고압처리장치(Y사, Daegu, Korea)를 이용하여 $25 \mathrm{kgf} / \mathrm{cm}^{2}$ 압력조건으로 5 분간 처리하였고 $60^{\circ} \mathrm{C}$ 에서 3 시 간 $10 \%$ 에탄올 추출 $(1: 20, \mathrm{w} / \mathrm{v})$ 한 다음 감압 여과 후 고형분을 사용하였다. 
Effects of the Physicochemical Properties of Lignocellulosic Artificial Soil Containing Bacillus subtilis on the Growth of Lespedeza cyrtobotrya

\section{2. 미생물 제형 및 인공토양 조제}

공시균주인 Bacillus subtilis는 경남 진주소재의 $\mathrm{H}$ 사에서 제공받아 이용하였다. 미생물을 $\mathrm{NB}$ 배지에서 4 일간 $30^{\circ} \mathrm{C}, 100$ $\mathrm{rpm}$ 조건으로 액체배양 하였고 멸균된 펄라이트 $100 \mathrm{~g}$ 에 액체 배양된 미생물 $30 \mathrm{~mL}$ 과 $2 \% \mathrm{CMC}$ (Carboxy Methyl Cellulose) $30 \mathrm{~mL}$ 을 넣어 혼합한 다음 $30{ }^{\circ} \mathrm{C}$ 배양기에서 8 일간 생장시켰다. 미생물 생장 후 $35{ }^{\circ} \mathrm{C}$ 건조기에서 48 시간 건조하였고 동결건조 기를 이용하여 미생물을 제형화 한 다음 인공토양 원료로 사용하였다. 인공토양은 전건중량을 기준으로 하여 피트모스, 펄라이 트, 전처리된 참나무 및 미생물 제형을 3:1:3:3 $(\mathrm{w} / \mathrm{w} / \mathrm{w} / \mathrm{w})$ 비율로 혼합하여 조제 하였다.

\section{3. 소규모 야외포트 실험구 조성}

소규모 야외포트 실험구 조성을 위해 대조구토양(경남 양산시 천성산 습지토양, $100 \%$ 토양), $25 \%$ 혼합토양(75\% 토양 + $25 \%$ 인공토양, w/w) $50 \%$ 혼합토양 $(50 \%$ 토양 $+50 \%$ 인공토양, w/w), $75 \%$ 혼합토양 $(25 \%$ 토양 + $75 \%$ 인공토양, w/w) 및 인공토양 $(100 \%$ 인공토양)을 각각 건조중량 기준으로 제조하였으며, $7.5 \times 7.5 \times 7.5 \mathrm{~cm}$ 정사각형 모양의 육면체 포트에 넣어 경남 진주시의 위도 $35.14 \mathrm{~N}$, 경도 $128.09 \mathrm{E}$ 비탈면에 임의배치법을 적용하여 시험구를 조성하였으며, 시험구 조성 후 3일에 한번씩 충분히 관수하여 토양이 건조하지 않도록 하였다. 조성된 시험구에는 목본류인 참싸리(Lespedeza cyrtobotrya) 종자를 50 립씩 파종하여 식물생장 분석에 이용하였고 대조구토양, 제조된 혼합토양 및 인공토양은 물리·화학적 특성과 미생물밀도 분석에 이용하였다.

\section{4. 물리·화학적특성 분석}

대조구토양, 제조된 혼합토양 및 인공토양은 $60^{\circ} \mathrm{C}$ 에서 24 시간 건조 후 물리·화학적 분석에 이용되었다. 용적밀도(Bulk density)는 $100 \mathrm{~cm}^{3}$ 코어 속에 시료를 채운 다음 $500 \mathrm{~g}$ 추를 이용하여 3분간 압력을 가해 다진 후 코어의 상단을 용기면에 수직으로 잘라낸 시료의 무게를 측정하여 산출하였고(CEN, 1999a, 1999b; Byun et al., 2012), 공극률(Porosity)은 용적밀도 측정 후 진비중값(2.65)을 이용하여 계산하였다(Inbar et al., 1993). 수분보유력(Water holding capacity)은 $100 \mathrm{~cm}^{3}$ 코어 속에 시료를 채우고, $500 \mathrm{~g}$ 추를 이용하여 3분간 압력을 가해 다진 다음 물로 포화시킨 후 24시간 동안 중력수가 제거된 시료 무게를 측정하고, 다시 $105^{\circ} \mathrm{C}$ 항온건조기에서 24시간 건조시킨 후 건조된 시료 무게를 측정하여 산출하였다(Yi et al., 2012). $\mathrm{pH}$ 는 시료에 증류수를 혼합하여(1:5, w/w) shaking incubator에서 30분간 진탕 후 현탁액을 $\mathrm{pH}$ meter (HI-8418, HANNA Instrument, USA)를 사용하여 측정하였고, 현탁액 여액은 EC meter (Orion 3-Star Plus, Thermo Fisher Scientific, USA)를 사용하여 전기전도도(EC, Electrical conductivity)를 측정하였다. 유기물 함량(Organic matter)은 $550^{\circ} \mathrm{C}$ 의 회화로에서 완전히 탄화시켜 측정하였고 (NIAST, 2000) 탄질비(C/N ratio)는 원소분석기(Flash 2000 Series, Thermo Fisher Scientific Inc., USA) 로 탄소 및 질소의 함량을 측정 후 탄소함량에 대한 질소 함량의 비율로 계산하였다.

\section{5. 식물생육 특성 분석}

식물생육 특성 분석을 위해 참싸리 종자 치상 후 3 개월째 발아한 유묘를 무작위로 5 개 임의선정 하였고 켈리퍼스(Digital calipers, Blue bird, China)를 이용하여 줄기(Stem height) 및 뿌리(Root length) 생장 길이를 측정하였다(Lee et al., 2013).

\section{6. 미생물밀도 분석}

미생물밀도 분석을 위해 현장적용 전 대조구토양, 제조된 혼합토양 및 인공토양과 현장적용 3 개월 후 대조구토양, 혼합토양, 인공토양 기건 중량기준 $10 \mathrm{~g}$ 을 각각 채취한 다음 $90 \mathrm{~mL}$ 의 멸균된 $0.85 \% \mathrm{NaCl}$ 용액에 넣어 진탕배양기 (Vision Co., Bucheon, Korea)에서 $200 \mathrm{rpm}$ 으로 30 분간 현탁하였다. 현탁액은 일련의 희석계열을 만든 후, cycloheximide $(0.05 \mathrm{~g} / \mathrm{L})$ 를 첨가한 R2A agar (NA, Difco, Detroit MI)배지에 도말하여 배양하였다. 도말된 평판은 $28{ }^{\circ} \mathrm{C}$ 에서 2 일간 배양한 후 출현한 colony를 계수하였 다. 각 시료당 미생물 수는 3개의 petridish에 나타난 colony를 각각 계수한 후 평균값을 생균수(colony forming unit: CFU/g)로 산출하였다(Oh et al., 2014).

\section{7. 통계분석}

데이터 통계분석은 IBM SPSS statistics v25 (IBM Corp., Armonk, NY, USA) 프로그램을 이용하였다. 처리구 평균간 유의성 검정을 위해 Duncan's multiple rage test $(p<0.05)$ 를 실시하였고 인공토양의 물리·화학적 특성인자와 참싸리의 줄기 및 뿌리 생장과의 상관관계는 피어슨 상관계수(Pearson’s correlation coefficients)분석을 실시하였다. 


\section{3. 결과 및 고찰}

\section{1 물리적 특성}

토양의 물리적 특성인 용적밀도, 공극률, 수분보유력등은 식물의 생장에 큰 영향을 미치는 요소로 작용하기 때문에(Boodley, 1998) 대조구토양과 인공토양의 혼합에 따른 물리적 특성 비교가 중요하다. Table 1 에 대조구토양과 혼합토양 및 인공토양에 대한 용적밀도, 공극률 및 수분보유력을 나타냈다.

$25 \%$ 혼합토양 및 $50 \%$ 혼합토양은 각각 $0.24 \mathrm{~g} / \mathrm{cm}^{3}$ 및 $0.16 \mathrm{~g} / \mathrm{cm}^{3}$ 의 용적밀도를 나타냈는데 $0.51 \mathrm{~g} / \mathrm{cm}^{3}$ 의 용적밀도를 나타낸 대조구토양과 유의하게 낮은 수치를 나타냈고 인공토양의 혼합비율이 증가함에 따라 용적밀도는 점차 감소하는 경향을 나타냈다. 토양내 유기물함량과 용적밀도간에는 음(-)의 관계를 나타낸다고 알려져 있는데(Ju et al., 2015) 인공토양 혼합비율이 증가할수록 유기물 함량도 함께 증가하여 나타난 결과로 사료된다(Table 2). 인공토양으로 인해 낮아진 용적밀도는 보수성 또는 통기성 향상에 유리하게 작용할 것으로 판단된다(Nelson, 2003). 공극률은 토양의 배수력 및 보수력뿐만 아니라 식물근 생장에 영향을 주는 인자이며(Schoenholtz et al., 2000, Liebig and Doran, 1999), 85\%이상의 공극률에서 식물생장이 원활하게 이루어진다고 알려져 있다(De Boodt and Verdonck, 1972; Gruda and Schnitzler, 2004). 대조구토양은 식물생장에 적합한 공극률보다 낮은 $80.7 \%$ 의 공극률을 나타내었지만 인공토양의 혼합비율이 증가함에 따라 공극률은 $90.8 \%-95.5 \%$ 까지 유의하 게 증가되었다. 인공토양의 혼합으로 인한 공극률의 증가는 식물생장에 유리하게 작용할 것으로 판단된다. 다만, 토양에서의 수분이동은 공극을 통하여 이루어지는데 높은 공극률로 인해 투수성이 높아지게 되면 식물에게 건조해를 입힐 우려가 있다(Shin, 2002). 따라서 $97.0 \%$ 의 높은 공극률을 나타낸 인공토양의 단독 이용보다는 현장 토양조건에 맞추어 인공토양의 적절한 배합이 고려되어야 할 것으로 판단된다. 수분보유력은 인공토양의 수분저장능력을 나타내고 식물 생장에 필요한 수분 공급에 영향을 미치는 인자로 알려져 있다(Yang et al., 2013). 대조구토양, $25 \%$ 혼합토양, $50 \%$ 혼합토양, $75 \%$ 혼합토양 및 인공토양의 수분보유력은 각각 59.9\%, 66.1\%, 76.5\%, 79.8\% 및 83.3\%로 나타났으며 인공토양 혼합비율이 증가함에 따라 수분보유력이 유의하게 증가하였고 대조구토양을 제외한 모든 처리구에서 적정 수분보유력인 $60 \%$ 이상의 수치를 나타냈다(Yeager et al. 1997). Basso et al. (2013)과 Lawes et al. (2009)은 높은 수분보유력은 장기간 식물생장에 유리할 뿐만 아니라 토양유실 방지에 효과를 나타낸다고 보고했다. 따라서 제조된 인공토양은 장기간 식물생장 및 현장적용시 환경적인 요인으로 인한 토양유 실에 효과적일 것으로 사료된다. 또한 대조구토양에 대하여 인공토양의 혼합비율이 커질수록 용적밀도, 공극률 및 수분보유력이 향상되는 것으로 나타났다.

\section{2. 화학적 특성}

토양의 화학적 특성은 식물생장에 직접적으로 관여하거나 식물생육에 적합한 환경을 결정하는 중요한 요인으로(Gabriels et al., 1986) 대조구토양과 인공토양의 혼합비율에 따른 화학적 특성 분석 비교가 필요하다. 대조구토양, 혼합토양 및 인공토양에 대한 $\mathrm{pH}$, 전기전도도(EC, electrical conductivity), 탄질비(C/N ratio) 및 유기물 함량(Organic matter)을 Table 2에 나타냈다.

대조구토양, $25 \%$ 혼합토양, $50 \%$ 혼합토양 및 $75 \%$ 혼합토양의 $\mathrm{pH}$ 는 각각 $\mathrm{pH} 4.8, \mathrm{pH} 4.7$ 및 $\mathrm{pH} 4.6$ 로서 식물생장에 적합한 pH 5.3 - 6.5 보다 낮은 수치를 나타냈고(Abad et al., 1992) 인공토양의 혼합비율에 따른 유의성을 나타내지 않았다. 또한, 인공토양에서는 가장 낮은 $\mathrm{pH}$ 4.3을 나타냈는데 Yamazaki (1982)는 $\mathrm{pH} 4$ 이하에서는 식물의 뿌리가 손상을 받기 쉽다고 보고하였다. 따라서 적용 현장조건에 따라 인공토양의 $\mathrm{pH}$ 조정이 필요하다고 판단된다. 대조구토양, 혼합토양 및 인공토양의 전기전도도는 전체적으로 $0.061-0.101 \mathrm{ds} / \mathrm{m}$ 를 나타냈다. 식물생육에 적합한 전기전도도는 일반적으로 $0.5 \mathrm{ds} / \mathrm{m}$ 이하가 적정한 것으로 알려져 있고(Abad et al., 2001) 높은 전기전도도는 염류집적으로 인하여 식물의 뿌리생장에 불리하다(Aliasgharzadeh et al., 2001). 따라서 인공토양은 낮은 전기전도도로 인하여 염류에 대한 식물생장 피해를 나타내지 않을 것으로 판단된다. 일반적으로 탄질비가 높아지게 될 경우 근권부에 존재하는 질소를 식물이 이용하기 전 미생물이 먼저 흡수하게 되어 초기생육이 불량하게 된다(Choi et al., 2011). 이로 인해 인공토양의 탄질비가 50 이상일 경우에는 질소비료를 첨가하여 탄질비를 조절해야 한다고 알려져 있다(Lee and Sang, 1991). Sou et al. (2011)은 참싸리 자생지에 대한 탄질비가 17.4로 나타났다고 보고하였는데 $25 \%$ 혼합토양, $50 \%$ 혼합토양 및 $75 \%$ 혼합토양에서는 15.0 - 19.8 범위의 탄질비를 나타내어 인공토양의 혼합으로 인한 초기생육 문제는 발생하지 않을 것으로 판단된다. 대조구토양의 유기물 함량은 $23.6 \%$ 로 가장 낮은 수치를 나타냈고 인공토양 혼합비율이 증가할수록 $27.6 \%$ - 43.2\%로 유기물 함량이 유의성 있게 증가하였다. 이는 인공토양 제조를 위해 사용된 유기물 원료인 전처리된 참나무 및 피트모스의 혼합으로 인한 영향으로 판단되며, 유기물함량의 증가는 식물생장을 위한 다량 영양소 제공 및 미량 영양소 교환을 위한 양이온 치환능력에 유리할 것으로 판단된다(Wood et al., 2018). 
Effects of the Physicochemical Properties of Lignocellulosic Artificial Soil Containing Bacillus subtilis on the Growth of Lespedeza cyrtobotrya

\section{3. 미생물밀도}

대조구토양, 혼합토양 및 인공토양의 소규모 야외포트 현장적용 전·후 미생물 밀도변화를 Table 3에 나타냈다.

현장적용 전 대조구토양의 미생물밀도는 $35 \times 10^{6} \mathrm{CFU} / \mathrm{g}$ 으로 가장 낮은 수치를 나타냈고 인공토양 혼합비율이 증가할수록 미생물밀도도 $157 \times 10^{6} \mathrm{CFU/g}$ 에서 $624 \times 10^{6} \mathrm{CFU/g}$ 으로 증가하였다. 소규모 야외포트 현장적용 3개월 후 대조구토양의 미생물밀도는 $13.4 \%$ 감소하였고 $25 \%$ 혼합토양, $50 \%$ 혼합토양, $75 \%$ 혼합토양 및 인공토양의 미생물 함량은 각각 $61.1 \%$, $30.8 \%, 21.0 \%$ 및 $36.9 \%$ 증가한 수치를 나타냈다. 이러한 이유는 미생물은 영양원으로 유기성 탄소원과 질소원을 다량원소로 이용하며 생장하게 되는데 제조된 인공토양은 유기질로 이루어진 피트모스 및 목질계 원료가 포함되어있어, 미생물이 생육하는 데 양호한 환경이 조성되어 나타난 결과로 판단되고(Barber and Lynch, 1997; Lynch, 1982; Krieg and Holt, 1984) 증가된 미생물밀도는 식물생장에 긍정적인 영향을 미칠 것으로 사료된다(Nautiyal et al., 2013).

\section{4. 생육특성}

대조구토양, 혼합토양 및 인공토양의 소규모 야외포트 현장적용 시험구에 파종된 참싸리에 대한 줄기생장(stem height) 및 뿌리생장(root length)을 Fig. 1에 나타냈다.

참싸리의 줄기생장 길이는 $25 \%$ 혼합토양에서 $5.1 \mathrm{~cm}$ 로 가장 높은 수치를 나타냈고 $50 \%$ 혼합토양, $75 \%$ 혼합토양 및 인공토 양에서는 각각 $4.8 \mathrm{~cm}, 4.4 \mathrm{~cm}$ 및 $3.5 \mathrm{~cm}$ 로 나타나 $50 \%$ 이상 인공토양을 혼합하였을 때 줄기생장이 감소하였다. 참싸리의 뿌리생장은 $50 \%$ 혼합토양에서 $11.9 \mathrm{~cm}$ 의 가장 높은 수치를 나타냈고 $25 \%$ 혼합토양, 대조구토양, $75 \%$ 혼합토양 및 인공토양 순으로 각각 $10.5 \mathrm{~cm}, 8 \mathrm{~cm}, 7 \mathrm{~cm}$ 및 $5 \mathrm{~cm}$ 로 나타났다. 인공토양은 토양의 투수성 및 통기성을 증진시킴으로서 식물생장을 개선한다고 알려져 있는데(Warkentin, 1984; Kang et al., 2004) 인공토양의 혼합량에 비례하여 줄기생장 및 뿌리생장 길이는 증가하지 않았다. 따라서 식물에 따른 적절한 인공토양 혼합비 조절이 필요할 것으로 판단된다.

\section{5. 인공토양의 물리·화학적 특성과 참싸리 생장에 대한 상관관계}

참싸리의 줄기 및 뿌리생장에 영향을 미치는 토양의 물리·화학적 특성인자를 도출하기 위한 상관관계 분석결과를 Table 4에 나타냈다.

참싸리 줄기생장과 인공토양의 물리·화학적 특성 인자간 상관관계를 확인하였을 때 미생물밀도, 탄질비, 유기물 함량 및 수분보유력이 유의한 양 $(+)$ 의 상관관계를 나타냈다 $(p<0.01)$. 특히, 미생물밀도와 참싸리의 줄기생장은 0.599 의 가장 높은 양(+)의 상관관계를 나타냈으며, Jo et al.(2017)은 공극률과 식물의 줄기생장은 양 $(+)$ 의 상관관계를 나타낸다고 보고하였는데 이와 일치한 결과를 나타냈다. 참싸리의 뿌리생장은 용적밀도와 유의한 양 $(+)$ 의 상관관계를 나타냈고 $(p<0.01)$ 공극률, 수분보유 력, 탄질비 및 유기물함량과는 유의한 부(-)의 상관관계를 나타냈다.

\section{4. 결 론}

인공토양을 대조구토양과 혼합하였을 때 $0.4 \mathrm{~g} / \mathrm{cm}^{3}$ 보다 낮은 용적밀도와 $85 \%$ 의 이상의 공극률, $60 \%$ 이상의 수분보유력을 나타냈고 화학적 특성에서는 $0.5 \mathrm{ds} / \mathrm{m}$ 이하의 전기전도도, 50 이하의 $\mathrm{C} / \mathrm{N}$ ratio 및 높은 유기물 함량을 나타내어 식물생장에 적합한 물리·화학적 특성 범위에 포함되는 것으로 확인되었다. 다만, 제조된 인공토양의 $\mathrm{pH}$ 는 약산성을 나타내 현장적용에 따른 $\mathrm{pH}$ 조절이 필요할 것으로 판단된다. 참싸리의 줄기 및 뿌리 생장 길이를 비교한 결과 $25 \%$ 혼합토양 및 $50 \%$ 혼합토양에서 대조구토양보다 높은 참싸리 생장을 나타냈다. 참싸리의 줄기 및 뿌리 생육에 영향을 미치는 인공토양의 물리·화학적 특성 인자를 탐색한 결과 참싸리의 줄기생장에는 미생물밀도가 가장 큰 영향을 나타냈으며 뿌리생장에는 유기물 함량이 가장 큰 영향을 나타내는 것으로 확인되었다. 따라서 본 연구에서 제조된 인공토양은 참싸리 종자의 줄기생장 및 뿌리생장에 효과적인 것으로 나타나 녹화용 토양으로서 활용 가능할 것으로 사료된다. 